\title{
THE ROLE OF DOMESTIC AUTHORITIES IN EFFECTIVE APPLICATION OF ADVISORY OPINION PROCEDURE UNDER THE PROTOCOL № 16 TO THE CONVENTION FOR THE PROTECTION OF HUMAN RIGHTS AND FUNDAMENTAL FREEDOMS
}

The purpose of the article is to underline that the comprehensive implementation of the Protocol № 16 to the Convention for the Protection of Human Rights and Fundamental Freedoms depends on the appropriate efforts of the member States. Both the parliaments and the highest courts of the member States should take certain measures to achieve the goals persuaded by the Protocol. Thus, it is important to examine the risks of the Protocol's implementation to find out what specific activity should be performed by the member States to minimize problems and provide for maximum benefits.

In particular, advisory opinions are not biding, so the opinion of the European Court's of Human Rights may be ignored; it can lead to delays in the proceedings before the domestic courts themselves; there is a risk that it might generate additional workload for the Court. However, the risks can be managed and in the end the advantages of advisory opinion procedure's application outweigh its disadvantages.

The article involves some important recommandations for domestic parliaments to establish sufficient procedural rules and judicial bodies to make requests in proper manner. It is also argued that domestic parliaments should inter alia establish effective mechanisms of applying for advisory opinion by domestic courts and requests by domestic courts and tribunals should be based on appropriate guidelines and explanations. Sited recommandations are of great importance for Post-Soviet countries to apply the Protocol more correctly and widely. As the international experience of requesting for advisory opinion is quite poor, it makes examples of it even more significant. So, the article also introduces two sample cases of requesting for advisory opinion made by the French Court of Cassation and the Constitutional Court of Armenia accordingly. Getting acquainted with the content and the purposes of this experience will maintain the level of application of advisory opinion procedure.

Key words: request, domestic parliaments, domestic courts or tribunals, recommendations, procedural rules. 
Zarikyan Karen Barseghi, Lecturer at RussianArmenian University, Judge of the Administrative Court of Republic of Armenia,

$P h D$ in Law orcid.org/0000-0001-8849-7979 karenzarikyan@gmail.com

\section{Introduction}

On behalf of the member States of the Council of Europe and other High Contracting Parties to the Convention for the Protection of Human Rights and Fundamental Freedoms, signed at Rome on 4 November 1950 (hereinafter referred to as "the Convention"), considering that the extension of the European Court's of Human Rights (hereinafter referred to as "the Court") competence to give advisory opinions will further enhance the interaction between the Court and national authorities and thereby reinforce implementation of the Convention, the Protocol № 16 to the Convention (hereinafter referred to as "the Protocol") (Council of Europe, 2013c) has been adopted at Stratsbourg on 2 October 2013. According to the Article 1 of the Protocol the Highest courts and tribunals of High Contracting Parties may request the Court to give advisory opinions on questions of principle relating to the interpretation or application of the rights and freedoms defined in the Convention or the protocols thereto. According to the Opinion № 285 (2013) adopted by the Parliamentary Assembly of the Council of Europe on 28 June 2013, the Protocol is likely to: (1) strengthen the link between the Court and States' highest courts by creating a platform for judicial dialogue, thereby facilitating the application of the Court's case law by national courts; (2) help shift, from ex post to ex ante, the resolution of a number of questions of interpretation of the Convention's provisions in the domestic forum, saving - in the long run - the valuable resources of the Court; the speedier resolution of similar cases on the domestic plane will also reinforce the principle of subsidiarity (Council of Europe, 2013a). The Protocol is in force for number of the member States of the Council of Europe, including some Post-Soviet States (Armenia, Estonia, Georgia, Lithuania, Ukraine), as of 1 September 2019 (European Court of Human Rights, 2017a).

The Court's advisory opinions should obviously help the member States to interpret and apply the Convention more effectively and protect human rights more sufficiently. Having in mind the rules given by the Court in its advisory opinions, the highest courts and tribunals of the member States would gain unprecedent opportunity to decide on the case pending before them in accordance with the Convention and avoid future possible violations of the Convention.

As the Court mentioned in its Opinion for the Izmir Conference adopted on 4 April 2011 (Council of Europe, 
2011), the idea of allowing national courts to seek advisory opinions aimed at reinforcing domestic implementation of the Convention in accordance with the principle of subsidiarity (European Court of Human Rights, 2013: para. 2). Moreover, it has been argued in the Wise Persons' Report of 2006 that an extended advisory jurisdiction would enhance the Court's "constitutional" role (Council of Europe, 2007: § 81). Advisory opinions provide an opportunity to develop the underlying principles of law in a manner that will speak to the legal systems of all the Contracting Parties (O'Boyle, 2010: 11-12). They may therefore be of comparable significance to the Court's leading judgments and foster a harmonious interpretation of the minimum standards set by the Convention rights and thus an effective protection of human rights throughout the Contracting States (European Court of Human Rights, 2013: para. 5).

Extending the Court's advisory jurisdiction so as to allow domestic courts of last instance to obtain an advisory opinion from the Court on questions concerning the interpretation of the Convention could serve to create an institutionalised dialogue between these domestic courts and the Court (Council of Europe, 2007: $\S 81$ ). They would provide an occasion to have a discussion on essential questions concerning the interpretation of the Convention in a possibly larger judicial forum (European Court of Human Rights, 2013: para. 5). They could complement the existing pilot-judgment procedure (Rule 61 of the Rules of Court) without necessarily being limited to cases revealing structural or systemic problems in a Contracting State ${ }^{1}$. The procedure would thus allow the Court to adopt a larger number of rulings on questions of principle and to set clearer standards for human rights protection in Europe (European Court of Human Rights, 2013: para. 5).

An advisory opinion procedure could also serve to avoid controversies between domestic courts and the Court. As it would be for the domestic courts of last instance to implement the Court's advisory opinions, such a procedure could diminish any national susceptibilities with regard to the Court's case-law ${ }^{2}$.

However, there can be reasonable doubts that the Protocol's application may also cause negative effects. Firstly, according to the Article 5 of the Protocol advisory opinions are not biding, so the Court's opinion may be ignored; secondly, it can lead to delays in the proceedings before the domestic courts themselves; thirdly, there is a risk that it might generate additional workload for the Court.

The aim of this article is to underline that the comprehensive implementation of the Protocol depends on the appropriate efforts of the member States. As expressed in the Opinion of the Court for the Izmir Conference, an implementation of the Convention by the domestic courts in that manner (using advisory opinions) would further emphasise their crucial role in applying the Convention and thus reinforce the principle of subsidiarity ${ }^{3}$. An advisory opinion procedure would therefore fully be in line with

${ }^{1}$ See the report presented by the Norwegian and Dutch experts to the DH-S-GDR (European Court of Human Rights, 2013: para. 5).

${ }^{2}$ See also the report of the Norwegian and Dutch experts to the DH-S-GDR (European Court of Human Rights, 2013: para. 6).

3 See Opinion of the Court for the Izmir Conference, adopted by the Plenary Court on 4 April 2011 (doc. № 3484768) and the report presented by the Norwegian and Dutch experts to the DH-S-GDR (European Court of Human Rights, 2013: para. 9). 
the Action Plan agreed upon in the Interlaken Declaration of 19 February 2010, in which the Conference stressed the joint responsibility of the State Parties and the Court in securing the rights set forth in the Convention. It pointed out that it was first and foremost the responsibility of the States to guarantee the implementation of the Convention rights (Council of Europe, 2010: $§ 4,9$ ). Having regard to the Court's current workload, a reinforcement of the national courts' role in applying the Convention is of the utmost importance and all tools working towards that end should be seriously examined (European Court of Human Rights, 2013: para. 9).

Both the parliaments and the highest courts of the member States should take certain measures to achieve the goals persuaded by the Protocol. I believe that the authorities of the member States overcome the risks mentiond above if their actions are in accordance with the aims of the Protocol, its guidelines and explainations. Thus, the risks of the Protocol's implementation should be carefully examined to find out what specific activity should be performed by the member States to minimize problems and provide for maximum benefits.

The advisory opinion under the Protocol is of special importance for Post-Soviet states. In most of cases pending against these states the Court finds violations of conventional rights $^{4}$. Our countries are still in transition period from socialism to democracy and the role of the Convention and the Court are of great importance in stimulating democratic processes. So the Protocol's proper implementation may help these countries overcome transition period due to extension of the democratic mechanisms and faults reduction.

\section{Non-biding character of advisory opinions}

According to the Article 5 of the Protocol advisory opinions are not biding. Moreover, the fact that the Court has delivered an advisory opinion on a question arising in the context of a case pending before a domestic court would not prevent a party to that case subsequently exercising their right of individual application, i.e. they could still bring the case before the Court (Council of Europe, 2013b: para. 26). Thus, someone may consider that domestic courts will not follow a non-binding advisory opinion.

Advisory opinions, like other rulings of the Court (judgments and decisions), provide an authoritative statement by the Court on the standard of protection of the rights and freedoms guaranteed by the Convention (Paprocka, Ziółkowski, 2015: 290). Such a standard should be taken into account in the process of interpretation of the law by courts or tribunals within the scope of their competence ${ }^{5}$. It can be argued that the obligation to consider the opinions, to prevent violations of individual rights or interrupt existing

${ }^{4}$ For example, as of 2018, from 103 cases pending against Armenia in 94 the Court found at least one violation; from 157 cases pending against Azerbaijan in 151 the Court found at least one violation; from 90 cases pending against Georgia in 70 the Court found at least one violation; from 1304 cases pending against Ukraine in 1274 the Court found at least one violation (European Court of Human Rights, 2018).

${ }^{5}$ For more in the context of the ECtHR's judgments, see Polish Constitutional Tribunal judgment of 15 July 2010, case K 63/07, OTK ZU/3/A/2010/60; Polish Constitutional Tribunal judgment of 3 March 2005, case P 8/03, OTK ZU/3/A/2005/20 (Gerards, 2014; Paprocka, Ziółkowski, 2015: 290). For more on different aspects of being bound by Strasbourg standards, see also (Krzyżanowska-Mierzewska, 2008). 
violations, and the obligation not to challenge the interpretation adopted by the Court are exemplifications of the positive realisation of Article 1 of the Convention as well as the obligation to respect the Court's authority (Bodnar, 2014; Paprocka, Ziółkowski, 2015: 292). These obligations apply to the same extent to requesting courts and tribunals and to other national authorities (Paprocka, 2012: 80-85; Paprocka, Ziółkowski, 2015: 292). In this view, the Court notably did not appear to run a real risk of its authority being questioned by a domestic court not following its advisory opinion (European Court of Human Rights, 2013: para. 7). It appeared rather unlikely that a domestic court asking for the Court's advice would subsequently not follow it $^{6}$. After all, the fact that a domestic court applies for an advisory opinion stresses itself respect to the Court.

It should also be mentioned that domestic courts must bring serious reasons when deciding not to apply the Court's advisory opinion. Domestic parliaments may establish appropriate rules on this issue. Domestic courts should in turn bring weighty arguments on the fact of not applying the Court's advisory opinion in certain circumstances.

\section{Delays of domestic proceedings}

It is obvious that a request for an advisory opinion of the Court would lead to delays in the proceedings before the domestic courts themselves. Those in favour of the proposal countered that these delays should not be very significant and that the overall resolution of the specific case would not be delayed in cases which would otherwise be dealt with later by the Court anyway following an individual application ${ }^{7}$.

Moreover, requests for advisory opinions are treated by the Court as a matter of priority (European Court of Human Rights, 2016). Where a requesting court is of the view that a request warrants urgent consideration it should so inform the Court and give reasons for requesting an expedited procedure. Requesting courts should clearly indicate in the letter accompanying their request their wish that the matter be dealt with urgently. It is further recommended in Guidelines that the words "URGENT: PROTOCOL № 16" be inserted at the top of each page of the request (European Court of Human Rights, 2017a: para. 15). The Court will have regard to its own criteria governing the order in which applications lodged under Article 34 of the Convention are handled (European Court of Human Rights, 2017b).

Thus, domestic courts can avoid the delays in the proceedings before themselves in case they formulate their requests in accordance with the Guidelines' recommendations.

\section{The Court's workload}

One of the main concerns with regard to an extension of the Court's advisory jurisdiction is that, instead of leading to the intended decrease in the number of cases pending before the Court, it would increase the Court's workload ${ }^{8}$. It is clear that introducing a new procedure before the Court will lead to a new group of cases pending before it that would not otherwise be presented at that stage. In that context, it has to

${ }^{6}$ See also the view presented by the Norwegian and Dutch experts to the DH-S-GDR (European Court of Human Rights, 2013: para. 7).

${ }^{7}$ See for this argument the document presented by the Norwegian and Dutch experts to the DH-S-GDR (European Court of Human Rights, 2013: para. 11)

${ }^{8}$ See also the report presented by the Norwegian and Dutch experts to the DH-S-GDR (European Court of Human Rights, 2013: para. 12). 
be borne in mind that the Court, and in particular the Grand Chamber which may be called upon to decide on requests for advisory opinions, is already facing a very heavy workload (European Court of Human Rights, 2013: para. 13).

At the same time, by giving guidance concerning the interpretation of the Convention while cases are still pending before the domestic courts, the Court would allow cases which may end up at the Court anyway - to be settled already at national level (European Court of Human Rights, 2013: para. 14). The Court could clarify issues relating to the interpretation of the Convention at an early stage and thereby anticipate and prevent a possibly large number of individual applications raising the same issue from being lodged with it (European Court of Human Rights, 2013: para. 14). Working in that manner, could, in sum and in a mid- or long-term perspective, help reduce the Court's workload, as was stressed notably in the Izmir Declaration (Council of Europe, 2011).

It is important that domestic courts apply for advisory opinions only if a serious issue concerning conventional rights has been risen before themselves and there is no obvious solution in the Court's case law. Advisory opinion procedure should not replace the authority of domestic courts to resolve the case themselves by applying the Court's case law.

\section{Some other measures domestic parliaments should take}

Domestic parliaments as legislation bodies carry the responsibility of making appropriate procedural rules to ease requesting process of advisory opinions. Without appropriate procedural rules domestic courts may face some difficulties in requesting for an advisory opinion. At the same time, these rules should be flexible and the courts should have discretion when deciding on the issue case-by-case.

It is important that the appropriate procedural rules should be based on the Guidelines. In particular, according to the Guidelines: "A designated court or tribunal may submit a request for an advisory opinion to the Court as soon as it finds that the domestic proceedings before it give rise to a question or questions of principle relating to the interpretation or application of the rights and freedoms defined in the Convention or the Protocols thereto, and it considers that an opinion of the Court should be sought (Article $1 \S 2$ of the Protocol). Having regard to the various elements which go to make up a complete request, it is recommended that a request be lodged with the Court only after, in so far as relevant, the facts and legal issues, including issues of Convention law, have been identified. Depending on the position in domestic law, it may well be the case that one or both parties can take the initiative on this matter in their grounds of appeal against the decision of a lower court. In any event, the final decision on whether or not to request an advisory opinion rests with the appellate court or tribunal in so far as it has been designated a highest court or tribunal for the purposes of the Protocol" (European Court of Human Rights, 2017a: para. 10).

The Guidelines provide also for recommendations on the content of requests for an advisory opinion which is prescribed by Article $1 \S 3$ of Protocol № 16 and Rule 92 $\S 2.1$ of Chapter $\mathrm{X}$ of the Rules of Court. Such a request must contain not only the question or questions on which the court or tribunal concerned seeks the guidance of the Court but also the following additional elements: (a) the subject matter of the domestic case and its relevant legal and factual background; (b) the relevant domestic legal provisions; 
(c) the relevant Convention issues, in particular the rights or freedoms at stake; (d) if relevant, a summary of the arguments of the parties to the domestic proceedings on the question; (e) if possible and appropriate, a statement of the requesting court or tribunal's own views on the question, including any analysis it may itself have made of the question (European Court of Human Rights, 2017a: para. 12).

This recommendations should be implemented in the legislations of member States. It is mostly important especially for Post-Soviet states regarding some difficulties in application of the Convention.

Besides procedural rules domestic legislation bodies should also establish effective system of requiring advisory opinions. For instance, the fact that only high courts or tribunals can apply for an advisory opinion does not mean that other courts should not have a chance to resolve the case using the Court's opinion. Therefore, domestic parliaments should establish such judicial system where courts of lower instance may apply to appropriate court for requesting advisory opinion. It should be recommended that if a high court agrees with a court of a lower instance it applies to the Court for advisory opinion, if not - the case would be sent back to lower court. This kind of rules would make the Court's advisory opinion procedure more comprehensive, useful and preventing domestic courts from violation of human rights.

\section{Mechanisms of applying for advisory opinion by domestic courts}

Advisory opinions may have better effect if domestic courts request advisory opinions in proper manner. Besides appropriate legislation there should be practical skills of making requests. For developing such skills, the Guidelines and the Explanatory report (Council of Europe, 2013b) may be of great use. These Guidelines are intended to offer practical assistance on the initiation of and followup to the procedure set out in the Protocol to those courts or tribunals with competence to submit a request for an advisory opinion (European Court of Human Rights, 2017a: para. 1). The Explanatory report explains the reasoning behind this approach, namely limiting the number of courts empowered to avail themselves of the procedure, whilst leaving the Contracting Party a degree of flexibility to accommodate special features of its judicial system (Council of Europe, 2013b: para. 8).

In providing the relevant legal and factual background, the requesting court or tribunal should present the following: the subject matter of the domestic case and relevant findings of fact made during the domestic proceedings, or at least a summary of the relevant factual issues; the relevant domestic legal provisions; the relevant Convention issues, in particular the rights or freedoms at stake; if relevant, a summary of the arguments of the parties to the domestic proceedings on the question; if possible and appropriate, a statement of its own views on the question, including any analysis it may itself have made of the question (Council of Europe, 2013b: para. 12).

It is also important that the competent panel of the Court must give reasons for any refusal to accept a domestic court or tribunal's request for an advisory opinion, which is intended to reinforce dialogue between the Court and national judicial systems, including through clarification of the Court's interpretation of what is meant by "questions of principle relating to the interpretation or application of the rights and freedoms defined in the Convention or the Protocols thereto" and that would 
provide guidance to domestic courts and tribunals when considering whether to make a request and thereby help to deter inappropriate requests (Council of Europe, 2013b: para. 15).

Besides, domestic courts should be careful and apply to the Court for appropriate issues, linked to the interpretation and application of the Convention's rules.

The notion of "interpretation" can be understood in different ways (Zieliński, 2012: 48; Paprocka, Ziółkowski, 2015: 284; Senden, 2011: 7; Letsas, 2009). The request for an advisory opinion should be aimed at determining the scope of rights and freedoms guaranteed by the Convention, their content and permissible limitations (Paprocka, Ziółkowski, 2015: 284).

The notion of "application" under Article 1(1) of the Protocol should be understood as determining whether a particular type of case falls within the subjective, objective and temporal scope of the norm decoded from the Convention (Wróblewski et al., 1992); Paprocka, Ziółkowski, 2015: 285). A request for an advisory opinion cannot aim to transfer the dispute to the Court; the only aim can be to let the Court determine whether a particular right or freedom guaranteed by the Convention is applicable to the given category of factual circumstances identified by the national court (Paprocka, Ziółkowski, 2015: 285).

A question that can be the subject of an opinion must also be a question "of principle". Advisory opinions are supposed to facilitate the adjudication of individual cases pending before national courts and tribunals and serve as a tool for solving domestic problems which arise in the process of implementation of the standards of protection required by the Convention (European Court of Human Rights, 2013: para. 2). At the same time, the procedure for advisory opinions is supposed to contribute to the development of jurisprudence and enable clarification of issues which cause problems in several states-parties to the Convention (European Court of Human Rights, 2013: para. 30-31). Therefore the significance of the question raised in a request submitted under Article 1 of the Protocol should be assessed from both perspectives; one can assume that if the matter in question is important from one of those perspectives that should be enough to accept the request for examination by the Grand Chamber (Paprocka, Ziółkowski, 2015: 287).

\section{Experience of requesting for advisory opinion}

(A) The first request for an advisory opinion was introduced on 12 October 2018 by the French Court of Cassation. The Court of Cassation put the following questions to the Court:

"1. By refusing to enter in the register of births, marriages and deaths the details of the birth certificate of a child born abroad as the result of a gestational surrogacy arrangement, in so far as the certificate designates the "intended mother" as the "legal mother", while accepting registration in so far as the certificate designates the "intended father", who is the child's biological father, is a State Party overstepping its margin of appreciation under Article 8 of the European Convention for the Protection of Human Rights and Fundamental Freedoms? In this connection should a distinction be drawn according to whether or not the child was conceived using the eggs of the "intended mother"? 
2. In the event of an answer in the affirmative to either of the two questions above, would the possibility for the intended mother to adopt the child of her spouse, the biological father, this being a means of establishing the legal mother-child relationship, ensure compliance with the requirements of Article 8 of the Convention?"

In response to the request for an advisory opinion made by the French Court of Cassation, on 10 April 2019 the Court delivered the following opinion.

In a situation where, as in the scenario outlined in the questions put by the Court of Cassation, a child was born abroad through a gestational surrogacy arrangement and was conceived using the gametes of the intended father and a third-party donor, and where the legal parent-child relationship with the intended father has been recognised in domestic law:

1) the child's right to respect for private life within the meaning of Article 8 of the Convention requires that domestic law provide a possibility of recognition of a legal parent-child relationship with the intended mother, designated in the birth certificate legally established abroad as the "legal mother";

2) the child's right to respect for private life within the meaning of Article 8 of the Convention does not require such recognition to take the form of entry in the register of births, marriages and deaths of the details of the birth certificate legally established abroad; another means, such as adoption of the child by the intended mother, may be used provided that the procedure laid down by domestic law ensures that it can be implemented promptly and effectively, in accordance with the child's best interests (European Court of Human Rights, 2019b).

(B) The Constitutional Court of Armenia brought a request for an advisory opinion on 18 July 2019 launching the following questions:

1) Do the qualitative requirements (certainty, accessibility, predictability and sustainability) incur also to the concept of "law", which identifies an offence within the meaning of Article 7 of the Convention, and to the concept of "law" referred to in other articles of the Convention, for instance, in Articles 8-11?

2) If not, by what standards are they delineated?

3) Whether the criminal law, which contains a reference to certain legal provisions of legal acts that have a higher legal force and the highest possible legally binding power of abstraction and, by virtue of this, establishing an offence, meet the requirements of certainty, accessibility, predictability and sustainability?

4) In accordance with the principle of prohibition of the retroactive application of criminal law (part 1 of Article 7 of the Convention), which standards are provided for comparing the criminal law in force at the time of the commission of the offense and the amended criminal law, in order to disclose their contextual (essential) similarities or differences? (Constitutional Court of the Republic of Armenia, 2019a; Constitutional Court of the Republic of Armenia, 2019b)

The request for an advisory opinion was accepted by the Panel of the Grand Chamber on 2 October 2019 (European Court of Human Rights, 2019a). The requested advisory opinion has not beet adopted yet.

\section{Conclusions}

To sum up, the article is aimed to reveal the importance of the advisory opinion procedure that is making the interpretation and application of the Convention more 
effective and flawless. It becomes even more needed when it comes to countries that are eager to developing bases for rule of law.

Thus, the risks of the Protocol have been carefully studied to determine the measures domestic authorities should take to reach the goals of the Protocol. The article therefore involves some important recommendations for domestic parliaments to establish sufficient procedural rules and judicial bodies to make requests in proper manner. These recommendations are of great importance for Post-Soviet countries to apply the Protocol more correctly and widely.

As the international experience of requesting for advisory opinion is quite poor, it makes examples of it even more significant. That is why the article also introduces two sample cases of requesting for advisory opinion made by the French Court of Cassation and the Constitutional Court of Armenia accordingly. Getting acquainted with the content and the purposes of this experience will maintain the level of application of advisory opinion procedure. Based on the above I believe that this article must be regarded as the necessary step in researches made in this field.

\section{Bibliography:}

1. A request by the Constitutional Court of Armenia for an advisory opinion under Protocol № 16 has been accepted : Press Release issued by the Registrar of the Court on 11 October 2019, ECHR 343 (2019) / European Court of Human Rights. URL: http://hudoc.echr.coe.int/app/ conversion/pdf $/$ library $=$ ECHR\&id $=003-6534292-8633878 \&$ filename $=$ Court $\% 20$ accepts $\% 20$ the $\% 20$ Armenian $\% 20$ Constitutional $\% 20$ Court.

2. Advisory Opinion concerning the recognition in domestic law of a legal parent-child relationship between a child born through a gestational surrogacy arrangement abroad and the intended mother, requested by the French Court of Cassation (Request № P16-2018-001), 10 April 2019 / European Court of Human Rights. URL: https://hudoc.echr.coe.int/eng\#\{\%22ite $\operatorname{mid} \% 22:[\% 22003-6380464-8364383 \% 22]\}$.

3. Amendments to the Rules of the Court adopted by the Plenary Court on 19 September 2016 (Rules 1, 24, 29, 34, 44 and 82, new Chapter X) / European Court of Human Rights. URL: https://www.echr.coe.int/Documents/Rules_amended_P16_ENG.pdf.

4. Bodnar A. Res Interpretata: Legal Effect of the European Court of Human Rights' Judgments for Other States Than Those Which Were Party to the Proceedings. Human Rights and Civil Liberties in the 21st Century / Y. Haech, E. Brems (eds.). Dordrecht, 2014. P. 223-262.

5. Draft Protocol № 16 to the Convention for the Protection of Human Rights and Fundamental Freedoms : the Opinion № 285 (2013) adopted by the Parliamentary Assembly of the Council of Europe on 28 June 2013 / Council of Europe. URL: http://assembly.coe.int/nw/xml/ XRef/Xref-XML2HTML-EN.asp?fileid=20015\&lang=en.

6. Explanatory Report to Protocol № 16 to the Convention for the Protection of Human Rights and Fundamental Freedoms. / Council of Europe. Strasbourg, 2013. URL: https://www.echr.coe.int/Documents/Protocol_16_explanatory_report_ENG.pdf.

7. Gerards J. Advisory Opinions, Preliminary Rulings and the New Protocol № 16 to the European Convention on Human Rights: A Comparative and Critical Appraisal. Maastricht Journal of European and Comparative Law. 2014. Vol. 21. Issue 4. P. 633-636.

8. Guidelines on the implementation of the advisory-opinion procedure introduced by Protocol № 16 to the Convention (as approved by the Plenary Court on 18 September 2017) / European Court of Human Rights. URL: https://www.echr.coe.int/Documents/Guidelines_P16_ENG.pdf.

9. Interlaken Declaration, adopted at the High Level Conference on the Future of the European Court of Human Rights organised within the framework of the Swiss Chairmanship of the 
Committee of Ministers of the Council of Europe in Interlaken, Switzerland, on 18-19 February 2010 / Council of Europe. URL: https://www.echr.coe.int/Documents/2010_Interlaken_FinalDeclaration_ENG.pdf.

10. Izmir Declaration, adopted at the High Level Conference on the Future of the European Court of Human Rights organised within the framework of the Turkish Chairmanship of the Committee of Ministers of the Council of Europe in Izmir, Turkey, on 26-27 April 2011 / Council of Europe. URL: https://www.echr.coe.int/Documents/2011_Izmir_FinalDeclaration_ENG.pdf.

11. Krzyżanowska-Mierzewska M. The Reception Process in Poland and Slovakia. A Europe of Rights: The Impact of the ECHR on National Legal Systems / H. Keller, A. Stone-Sweet (eds.). Oxford ; New York : Oxford University Press, 2008. P. 543-548.

12. Letsas G. A Theory of Interpretation of the European Convention on Human Rights. Oxford, 2009. $140 \mathrm{p}$.

13. O'Boyle M. The Convention system as a subsidiary source of law. Strengthening Subsidiarity: Integrating the Strasbourg Court's Case law into National Law and Judicial Practice : Contribution to the Conference on the Principle of Subsidiarity, Skopje, 1-2 October 2010. Skopje, 2010. P. 10-15. URL: http://www.assembly.coe.int/CommitteeDocs/2010/20101125_skopje.pdf.

14. On suspension of the proceedings of the case of conformity of article 300.1 of the Criminal Code of the Republic of Armenia with the Constitution on the basis of the applications of Robert Kocharyan : Decision of the Constitutional Court of the Republic of Armenia on 18 July 2019, PDCC-81 / Constitutional Court of the Republic of Armenia. URL: http://concourt.am/ english/decisions/working/pdf/2019/81.pdf.

15. On suspension of the proceedings of the case of conformity of part 1 of article 300.1 of the Criminal Code of the Republic of Armenia with the Constitution on the basis of the application of the First Instance Court of General Jurisdiction of Yerevan : Decision of the Constitutional Court of the Republic of Armenia on 18 July 2019, PDCC-82 / Constitutional Court of the Republic of Armenia. URL: http://concourt.am/english/decisions/working/pdf/2019/82.pdf.

16. Paprocka A. Wpływ orzecznictwa ETPCz na rozumienie konstytucyjnych praw i wolności w Polsce - kilka uwag na marginesie orzecznictwa Trybunału Konstytucyjnego. XV lat obowiazywania Konstytucjiz 1997 r. Ksiega jubileuszowa dedykowana Zdzisławowi Jaroszowi / M. Zubik (ed.). Warszawa : Wydawnictwo Sejmowe, 2012. S. 80-85.

17. Paprocka A., Ziółkowski M. Advisory opinions under Protocol № 16 to the European Convention on Human Rights. European Constitutional Law Review. 2015. Vol. 11. Issue 2. P. 274-292. DOI: 10.1017/S1574019615000176.

18. Protocol № 16 to the Convention on the Protection of Human Rights and Fundamental Freedoms / Council of Europe. Strasbourg, 2013. URL: https://echr.coe.int/Documents/Protocol_16 ENG.pdf.

19. Reflection paper on the proposal to extend the Court's advisory jurisdiction (2013) / European Court of Human Rights. URL: https://www.echr.coe.int/Documents/2013_Courts_advisory_ jurisdiction_ENG.pdf.

20. Report of the Group of Wise Persons to the Committee of Ministers / Council of Europe. International Legal Materials. 2007. Vol. 46. Issue 1. P. 77-93. DOI: 10.1017/ S002078290000615X.

21. Senden H.C.K. Interpretation of Fundamental Rights in a Multilevel Legal System. Antwerp : Intersentia, 2011. 324 p.

22. The Court's Priority Policy (2017) / European Court of Human Rights. URL: https://www.echr.coe.int/Documents/Priority_policy_ENG.pdf.

23. Violations by Article and by State / European Court of Human Rights. HUDOC. 2018. URL: https://www.echr.coe.int/Documents/Stats_violation_1959_2018_ENG.pdf.

24. Zieliński M. Wykładnia prawa. Zasady, reguły, wskazówki. Warszawa : Lexis Nexis, 2012. $360 \mathrm{~s}$. 
25. Wróblewski J., Bankowski Z., MacCormick N. The Judicial Application of Law. Boston : Kluwer Academic Publishers, 1992. 357 p.

\section{References:}

1. European Court of Human Rights (2019a). A request by the Constitutional Court of Armenia for an advisory opinion under Protocol № 16 has been accepted: Press Release issued by the Registrar of the Court on 11 October 2019, ECHR 343 (2019). Retrieved from: http:// hudoc.echr.coe.int/app/conversion/pdf/?library=ECHR\&id=003-6534292-8633878\&filename $=$ Court $\% 20$ accepts $\% 20$ the $\% 20$ Armenian\%20Constitutional\%20Court [in English].

2. European Court of Human Rights (2019b). Advisory Opinion concerning the recognition in domestic law of a legal parent-child relationship between a child born through a gestational surrogacy arrangement abroad and the intended mother, requested by the French Court of Cassation (Request № P16-2018-001), 10 April 2019. Retrieved from: https://hudoc.echr.coe.int/eng\#\{\%22 itemid\%22:[\%22003-6380464-8364383\%22]\} [in English].

3. European Court of Human Rights (2016). Amendments to the Rules of the Court adopted by the Plenary Court on 19 September 2016 (Rules 1, 24, 29, 34, 44 and 82, new Chapter X). Retrieved from: https://www.echr.coe.int/Documents/Rules_amended_P16_ENG.pdf [in English].

4. Bodnar, A. (2014). Res Interpretata: Legal Effect of the European Court of Human Rights' Judgments for Other States Than Those Which Were Party to the Proceedings. Haech, Y., Brems, E. (eds.) Human Rights and Civil Liberties in the 21st Century. Dordrecht, pp. 223-262 [in English].

5. Council of Europe (2013a). Draft Protocol № 16 to the Convention for the Protection of Human Rights and Fundamental Freedoms: the Opinion № 285 (2013) adopted by the Parliamentary Assembly of the Council of Europe on 28 June 2013. Retrieved from: http://assembly.coe.int/ nw/xml/XRef/Xref-XML2HTML-EN.asp?fileid=20015\&lang=en [in English].

6. Council of Europe (2013b). Explanatory Report to Protocol № 16 to the Convention for the Protection of Human Rights and Fundamental Freedoms. Retrieved from: https://www.echr.coe.int/Documents/Protocol_16_explanatory_report_ENG.pdf [in English].

7. Gerards, J. (2014). Advisory Opinions, Preliminary Rulings and the New Protocol № 16 to the European Convention on Human Rights: A Comparative and Critical Appraisal. Maastricht Journal of European and Comparative Law, vol. 21, issue 4, pp. 633-636 [in English].

8. European Court of Human Rights (2017a). Guidelines on the implementation of the advisory-opinion procedure introduced by Protocol № 16 to the Convention (as approved by the Plenary Court on 18 September 2017). Retrieved from: https://www.echr.coe.int/Documents/Guidelines_P16_ENG.pdf [in English].

9. Council of Europe (2010). Interlaken Declaration, adopted at the High Level Conference on the Future of the European Court of Human Rights organised within the framework of the Swiss Chairmanship of the Committee of Ministers of the Council of Europe in Interlaken, Switzerland, on 18-19 February 2010. Retrieved from: https://www.echr.coe.int/Documents/2010 Interlaken_FinalDeclaration_ENG.pdf [in English].

10. Council of Europe (2011). Izmir Declaration, adopted at the High Level Conference on the Future of the European Court of Human Rights organised within the framework of the Turkish Chairmanship of the Committee of Ministers of the Council of Europe in Izmir, Turkey, on 26-27 April 2011. Retrieved from: https://www.echr.coe.int/Documents/2011_Izmir_FinalDeclaration_ENG.pdf [in English].

11. Krzyżanowska-Mierzewska, M. (2008). The Reception Process in Poland and Slovakia. Keller, H., Stone-Sweet, A. (eds.). A Europe of Rights: The Impact of the ECHR on National Legal Systems. Oxford; New York: Oxford University Press, pp. 543-548 [in English]. 
12. Letsas, G. (2009). A Theory of Interpretation of the European Convention on Human Rights. Oxford [in English].

13. O’Boyle, M. (2010). The Convention system as a subsidiary source of law. Strengthening Subsidiarity: Integrating the Strasbourg Court's Case law into National Law and Judicial Practice (Contribution to the Conference on the Principle of Subsidiarity, Skopje, 1-2 October 2010). Skopje, pp. 10-15. Retrieved from: http://www.assembly.coe.int/CommitteeDocs/2010/20101125_ skopje.pdf [in English].

14. Constitutional Court of the Republic of Armenia (2019a). On suspension of the proceedings of the case of conformity of article 300.1 of the Criminal Code of the Republic of Armenia with the Constitution on the basis of the applications of Robert Kocharyan: Decision of the Constitutional Court of the Republic of Armenia on 18 July 2019, PDCC-81. Retrieved from: http:// concourt.am/english/decisions/working/pdf/2019/81.pdf [in English].

15. Constitutional Court of the Republic of Armenia (2019b). On suspension of the proceedings of the case of conformity of part 1 of article 300.1 of the Criminal Code of the Republic of Armenia with the Constitution on the basis of the application of the First Instance Court of General Jurisdiction of Yerevan: Decision of the Constitutional Court of the Republic of Armenia on 18 July 2019, PDCC-82. Retrieved from: http://concourt.am/english/decisions/working/ pdf/2019/82.pdf [in English].

16. Paprocka, A. (2012). Wpływ orzecznictwa ETPCz na rozumienie konstytucyjnych praw i wolności w Polsce - kilka uwag na marginesie orzecznictwa Trybunału Konstytucyjnego [The Influence of the ECtHR's Jurisprudence on the Understanding of Fundamental Rights in Poland: A Few Remarks Related to the Constitutional Tribunal's Case-Law]. Zubik, M. (ed.). XV lat obowiazywania Konstytucjiz 1997 r. Księga jubileuszowa dedykowana Zdzisławowi Jaroszowi. Warszawa: Wydawnictwo Sejmowe, pp. 80-85 [in Polish].

17. Paprocka, A., Ziółkowski, M. (2015). Advisory opinions under Protocol № 16 to the European Convention on Human Rights. European Constitutional Law Review, vol. 11, issue 2, pp. 274-292. DOI: 10.1017/S1574019615000176 [in English].

18. Council of Europe (2013c). Protocol № 16 to the Convention on the Protection of Human Rights and Fundamental Freedoms. Strasbourg. Retrieved from: https://echr.coe.int/Documents/ Protocol_16_ENG.pdf [in English].

19. European Court of Human Rights (2013). Reflection paper on the proposal to extend the Court's advisory jurisdiction. Retrieved from: https://www.echr.coe.int/Documents/2013 Courts_advisory_jurisdiction_ENG.pdf [in English].

20. Council of Europe (2007). Report of the Group of Wise Persons to the Committee of Ministers. International Legal Materials, vol. 46, issue 1, pp. 77-93. DOI: 10.1017/ S002078290000615X [in English].

21. Senden, H.C.K. (2011). Interpretation of Fundamental Rights in a Multilevel Legal System. Antwerp: Intersentia [in English].

22. European Court of Human Rights (2017b). The Court's Priority Policy. Retrieved from: https://www.echr.coe.int/Documents/Priority_policy_ENG.pdf [in English].

23. European Court of Human Rights (2018). Violations by Article and by State. HUDOC. Retrieved from: https://www.echr.coe.int/Documents/Stats_violation_1959_2018_ENG.pdf [in English].

24. Zieliński, M. (2012). Wykładnia prawa. Zasady, reguły, wskazówki [Interpretation of Law: Principles, Rules, Instructions]. Warszawa: Lexis Nexis [in Polish].

25. Wróblewski, J., Bankowski, Z., MacCormick, N. (1992). The Judicial Application of Law. Boston: Kluwer Academic Publishers [in English]. 


\title{
РОЛЬ ВНУТРІШНІХ ОРГАНІВ ВЛАДИ В ЕФЕКТИВНОМУ ЗАСТОСУВАННІ ПРОЦЕДУРИ НАДАННЯ КОНСУЛЬТАТИВНОГО ВИСНОВКУ ЗГІДНО 3 ПРОТОКОЛОМ № 16 ДО КОНВЕНЦЇ̈ ПРО ЗАХИСТ ПРАВ ЛЮДИНИ І ОСНОВОПОЛОЖНИХ СВОБОД
}

\author{
Зарікян Карен Барсегі, \\ викладач Російсько-Вірменського університету, \\ суддя Адміністративного суду Республіки Вірменія, \\ кандидат юридичних наук \\ orcid.org/0000-0001-8849-7979 \\ karenzarikyan@gmail.com
}

\begin{abstract}
Метою статті є доведення факту, щзо всебічне виконання Протоколу № 16 до Конвениії про захист прав людини і основоположних свобод залежить від відповідних зусиль держав-членів. Як парламенти, так і верховні суди держав-членів повинні вжити певних заходів для досягнення иілей, зазначених у Протоколі № 16. Таким чином, важливо вивчити ризики впровадження Протоколу № 16, щоб з'ясувати, яку конкретну діяльність необхідно здійснити держсавамчленам для мінімізачії проблем та забезпечення максимальної вигоди.

Зокрема, консультативні висновки не включають пропозииії, тому думка Європейського суду з прав людини може бути проігнорована; ие може призвести до затримок у розгляді справ вітчизняними судами. С ризик створення додаткового навантаження на Свропейський суд з прав людини. Однак ризиками можна керувати. Зрештою, переваги застосування процедури надання консультативного висновку переважають над ї̈ недоліками.

Стаття містить важливі рекомендащії для вітчизняних парламентів щяодо встановлення достатньої кількості прочесуальних норм і судових органів для належного внесення запитів. Автор також стверджує, що вітчизняні парламенти повинні, зокрема, встановлювати ефективні механізми подання запитів щодо надання консультативних висновків вітчизняними судами, а запити внутрішніх судів та трибуналів мають базуватися на відповідних вказівках $і$ поясненнях. Зазначені рекомендащії дуже важливі для пострадянських країн у плані правильного й широкого застосування Протоколу № 16.

Оскільки міжнародний досвід запитів щодо надання консультативного висновку є незначним, наявні практики стають дедалі вагомішими. У статті представлені дві вибіркові справи про запит щодо надання консультативного висновку, зроблений Касащійним судом Франиії та Конституиіийним судом Вірменії. Ознайомлення зі змістом і иілями иъього досвіду дасть змогу підтримувати рівень застосування процедури надання консультативного висновку.
\end{abstract}

Ключові слова: запит, вітчизняні парламенти, вітчизняні суди чи трибунали, рекомендації, процесуальні норми. 